\title{
GCU
}

Glasgow Caledonian

University

University for the Common Good

\section{Why don't sexual offence complainers have a right to anonymity in Scotland?}

Tickell, Andrew

Published in:

Edinburgh Law Review

DOI:

10.3366/elr.2020.0658

Publication date:

2020

Document Version

Author accepted manuscript

Link to publication in ResearchOnline

Citation for published version (Harvard):

Tickell, A 2020, 'Why don't sexual offence complainers have a right to anonymity in Scotland?', Edinburgh Law Review, vol. 24, no. 3, pp. 427-434. https://doi.org/10.3366/elr.2020.0658

\section{General rights}

Copyright and moral rights for the publications made accessible in the public portal are retained by the authors and/or other copyright owners and it is a condition of accessing publications that users recognise and abide by the legal requirements associated with these rights.

Take down policy

If you believe that this document breaches copyright please view our takedown policy at https://edshare.gcu.ac.uk/id/eprint/5179 for details of how to contact us. 


\title{
Why don't sexual offence complainers have a right to anonymity in Scotland?
}

\author{
Andrew Tickell
}

(2020) Edinburgh Law Review 24(3)

\section{A. Introduction}

The prosecution of Alex Salmond on one count of attempted rape and thirteen counts of sexual assault in respect of ten complainers was always likely to stress-test aspects of our criminal justice system. The case represented the most high-profile sexual offences trial of the most high-profile person in modern Scottish legal history. Whatever the outcome, the identities of the complainers in this case were inevitably going to be the subject of intense press, political and public curiosity. The legal limits surrounding what could be published about their identities were always likely to be tested.

This article argues that the legal protection of complainer anonymity in sexual offence prosecutions in Scots law is nowhere near as robust as it should be. Despite popular misconceptions that sexual offence complainers are automatically given lifelong anonymity "under UK law," and can only be named in social media or print if they decide to "waive their anonymity", this article shows that complainer anonymity in Scotland generally relies - not on the force and sanctions of criminal law but on journalistic restraint, professional regulation, and the general tweeting public being ignorant of the fact that identifying sexual offence complainers remains perfectly lawful in most cases. I argue that the Scottish Parliament should reform this aspect of our criminal procedure as a matter of urgency to place complainer anonymity on a surer legal footing, to give complainers meaningful reassurances that their anonymity will be respected.

\section{B. Scottish criminal justice: an evolving media and regulatory landscape}

As recently as a decade ago, access to information about active court proceedings remained substantially mediated by traditional forms of media, in print, on TV and on the radio waves. This mediation was regulated - not just by law - but also by the professional and ethical preoccupations of journalists creating and reporting content. Reflecting their trade and training, this was also often informed by legal advice. Since the mid-2000s, the internet has transformed anybody with a smartphone or a laptop into a publisher with potential global reach. Social media platforms such as YouTube, Facebook and Twitter have not only challenged traditional media paradigms: they have 
also challenged traditional legal paradigms of the media, and how the law imagines its interactions with journalists and ordinary people with thumbs, opinions, fourteen Twitter followers, and no sense of restraint. The law in this area has, once again, proven slow to catch up with technological change. ${ }^{1}$

\section{Common misconceptions about complainer anonymity}

In terms of the mainstream press, the understood proprieties on reporting sexual crime are clear. As the Independent Press Standards Organisation's Guidance on Reporting Sexual Offences states:

All victims of sexual offences, including children, are automatically guaranteed anonymity for life from the moment they make an allegation that they are the victim of a sexual offence. A victim is guaranteed anonymity even when someone else accuses the defendant of the offence. In Scotland, the law is different but the practice of respecting anonymity is the same. ${ }^{2}$

The IPSO Guidance fails to amplify the critical legal distinction: not only is Scots law different on this point from England and Wales, but Scottish publishers are not required by law to respect the anonymity of sexual offence complainers, nor are they generally exposed to criminal sanctions for breaching that anonymity. Voluntarily withholding information on the grounds of professional ethics is not the same as being subject to a legal prohibition on publishing it, and critically, unaffiliated YouTubers, bloggers or tweeters are not subject to the complaints jurisdiction governing mainstream newspapers or broadcasters. Scottish public life seems blissfully unconscious of the legal insecurity of complainers' rights to anonymity.

\section{Complainer anonymity in Scotland: The Law}

Read from the Scottish perspective, the legislative scheme for victim anonymity may seem initially confusing. The Sexual Offences (Amendment) Act 1976 introduced the UK's first provisions on complainant anonymity in sexual offence cases. The modern law is expressed in the Sexual Offences

\footnotetext{
${ }^{1}$ In an earlier edition of this journal, I made the same point in respect of Scottish electoral law. See further: A Tickell, "Regulating \#indyref: Social Media and the Scottish Independence Referendum Act 2013" Edinburgh Law Review 18(3) $406-410$.

${ }^{2}$ Independent Press Standards Organisation (2020) Guidance on Reporting Sexual Offences available at https://www.ipso.co.uk/member-publishers/guidance-for-journalists-and-editors/guidance-on-reporting-ofsexual-offences/.
} 
(Amendment) Act of $1992 .^{3}$ Neither the 1976 nor the 1992 Act initially extended to Scotland, "except so far as it relates to courts-martial and the Courts-Martial Appeal Court." ${ }^{4}$ The anonymity these Acts provided for was also jurisdictionally circumscribed, only restricting the publication of a complainant's name, address, or picture in a "written publication" or "relevant programme" to be broadcast in England and Wales during that person's lifetime. ${ }^{5}$ This restriction was anchored in a list of qualifying sexual offences, set out in section 2. But under the 1992 Act as first enacted, it was not unlawful for the Scottish media to publish this information about an English complainant, and the publication of information about a Scottish complainer in a sexual offence case north of the border was not prohibited.

In England and Wales, complainant anonymity can be set aside in two main ways. Firstly, the trial judge can dispense with the anonymity if they are satisfied it represents a "substantial and unreasonable restriction upon the reporting of proceedings at the trial" and "it is in the public interest to remove or relax the restriction. ${ }^{\prime 6}$ Alternatively, complainants can effectively decide to waive their anonymity - affording anyone who publishes relevant information about them a defence if prosecuted. The 1992 Act attaches conditions, however. A complainant waiving anonymity must be (a) aged over sixteen years of age, (b) indicate their consent in writing, and (c) nobody can have "interfered unreasonably" with their "peace or comfort" to secure their consent. ${ }^{7}$ Dispensation of the court is not required.

The Youth Justice and Criminal Evidence Act 1999 broadened the 1992 Act's restrictions in two important respects. Firstly, the 1999 Act extended the prohibition to the publication of any material likely to give rise to the "jigsaw identification" of the complainant in sexual cases. In the language of the legislation, this means publishing any material "likely to lead members of the public to identify" them. ${ }^{8}$ The 1999 Act also amended the "extent" section of the anonymity legislation. This finally included Scotland within its strictures - but the effect of this change was much more limited than this might imply.

In 1999, no Scottish statutory or common law offences were added to the list of sexual crimes to which a right of complainer anonymity attaches. Westminster's restraint perhaps reflected a consciousness that the new Scottish Parliament would shortly assume responsibility for criminal justice policy under the Scotland Act - and may reach its own judgement about complainer

\footnotetext{
${ }^{3}$ Hereafter, "the 1992 Act."

41992 Act s 8(6).

51992 Act s 1(1) (as originally enacted).

61992 Act s 3(2)

71992 Act s 5(2) and (3).

81992 Act s 1(1) (as amended).
} 
anonymity. Since 1999, however, Holyrood has not added a single sexual offence to the list of crimes giving rise to that right. As a result, all the 1999 Act achieved was that Scottish publishers and broadcasters were now prohibited from identifying complainants in English or Welsh prosecutions for identified sexual offences, but the Act placed no new restrictions on Scottish publishers identifying - or publishing information likely to allow the public to identify - complainers in Scottish sexual offence cases.

What restrictions on the publication of this information can apply north of the border? The only legal tools available to Scottish courts are found in the Contempt of Court Act $1981 .{ }^{9}$ Section 1 of the 1981 Act establishes the strict liability rule, criminalising any publication which "tends to interfere with the course of justice in particular legal proceedings regardless of intent to do so." This offence applies to publications of any kind "which is addressed to the public at large or any section of the public," ${ }^{10}$ but to meet the threshold for strict liability, the publication must "create a substantial risk that the course of justice in the proceedings in question will be seriously impeded or prejudiced."11 Discussion of "public affairs or other matters of general public interest" in good faith" ${ }^{12}$ and "fair and accurate" reporting of legal proceedings "held in public, published contemporaneously and in good faith" are excluded from the ambit of section $1 .^{13}$

In most sexual offence cases, accurately identifying complainers would not seem to amount to a contempt of court under section 1 during the course of the trial, and importantly, could not do so once criminal proceedings had concluded. However, section 11 of the 1981 Act empowers the court to make additional orders prohibiting the publication of any "name or matter in connection with the proceedings as appear to the court to be necessary for the purpose for which it was so withheld," allowing courts explicitly to prohibit the identification of complainers in criminal or civil cases. ${ }^{14}$ Breach of contempt orders are punishable by two years' imprisonment, a fine, or both. ${ }^{15}$

In practice, however, it does not appear that making orders under section 11 is routine in sexual offence prosecutions in Scotland. The number of sexual offences pursued in Scotland's criminal courts substantially outstrips the number of orders made. In 2019, the Scottish Court and Tribunal Service records that 68 orders were made under the Contempt of Court Act by the Court of Session,

\footnotetext{
${ }^{9}$ Hereafter, "the 1981 Act."

101981 Act s 2(1).

111981 Act s 2(2).

121981 Act s 5 .

131981 Act s 4(1).

141981 Act s 11.

${ }^{15} 1981$ Act s 15(2).
} 
High Court, and Sheriff Courts. ${ }^{16}$ By way of context, in 2018/19, 1,762 people were proceeded against in Scotland's criminal courts for sexual offences, with 324 appearing on charges of rape or attempted rape alone. ${ }^{17}$ Of the 68 orders made under the Contempt of Court Act that year, just thirty-two were made under section 11. Interestingly, the overwhelming majority of section 11 orders seem to have been made during 2019 - not in criminal, but in civil - cases. Of the 32 section 11 orders made in 2019, just eight related to criminal cases, with the balance of 24 cases being made up of civil actions in the Sheriff Court and Court of Session, many of them bearing to concern allegations of medical negligence or historical child abuse. It is perhaps telling that in the case of $H M$ Advocate $v$ Alexander Salmond, despite the obvious dangers of complainers being identified on social media, an order was not made under section 11 of the 1981 Act prohibiting identification of the complainers until the $10^{\text {th }}$ of March 2020 - the second day of the trial diet.

\section{E. A Man v The Daily Record (2015)}

The significance of this gap between the law on the books and public expectations about rights to complainer anonymity is vividly demonstrated by a 2015 decision of the Complaints Committee of the IPSO in the Scottish case of $A$ Man $v$ the Daily Record. ${ }^{18}$ For ease of reference, I will call the complainer "Tom." In the Sheriff Court in 2015, the Sheriff acquitted a woman accused of sexually assaulting Tom. The judge also criticised the Crown's decision to bring the prosecution, on the basis that it was "hard to understand the decision making process by which it was found by the Crown to be in the public interest to pursue this case." ${ }^{19}$ The following day, the Daily Record published an article naming Tom as the complainer in this prosecution. In Tom's case, no order was made under section 11 of the Contempt of Court Act. In his complaint to IPSO about breaches of the Editors' Code, Tom claimed that the article:

caused him significant upset: it was humiliating to be identified in this way, and his family and friends had found out about the incident through reading about it in the newspaper. ${ }^{20}$

In their defence, the Record argued that "unlike in the rest of the UK, there is no specific provision in Scottish law which grants automatic anonymity to victims, or alleged victims, of sexual assault," ${ }^{21}$

\footnotetext{
${ }^{16}$ Scottish Court and Tribunal Service (2020) Contempt of Court Orders accessible at: https://www.scotcourts.gov.uk/current-business/court-notices/contempt-of-court-orders.

${ }^{17}$ Scottish Government (2019) Criminal Proceedings in Scotland 2018/19 https://www.gov.scot/publications/criminal-proceedings-scotland-2018-19/.

${ }^{18}$ A Man v the Daily Record (2015) IPSO Decision of the Complaints Committee 05764-15 https://www.ipso.co.uk/rulings-and-resolution-statements/ruling/?id=05764-15.

${ }^{19}$ Id para 6.

${ }^{20}$ Id para 3.

${ }^{21}$ Id para 5.
} 
and accordingly, they were "legally free" to publish Tom's identify. ${ }^{22}$ In terms of an "adequate justification" for doing so, the Record argued the Sheriff's criticism of the Crown justified revealing his name. The IPSO Complaints Committee found the publication had breached its Code, on the basis that:

The protection of the identities of people who make allegations of sexual assault is of great importance to society generally, and not just to those individuals at the centre of ongoing cases, as it is essential in ensuring that other victims are not dissuaded from reporting sexual offences to the police, for fear of unwanted publicity. ${ }^{23}$

From a legal perspective, the more jarring conclusion is that the Daily Record's submissions were entirely accurate.

\section{F. Distorted reporting restrictions for a social media age}

Complainer anonymity in sexual cases is not the only area where the intersection between Scottish legal regulation and new communications platforms remains strikingly unmodern. In 2019, the high profile murder case of HM Advocate $v$ Aaron Campbell demonstrated that the Scottish regulations applying to the identification of children in criminal proceedings are also beset by the anachronistic preoccupation with older media forms, undermining their impact and discriminating between old and new media forms in - arguably - indefensible ways. Under section 47 of the Criminal Procedure Scotland Act 1995, reporting restrictions apply to all court proceedings involving children. ${ }^{24}$ The concept of a "child" has been a mobile one in Scots law in recent years. The Victims and Witnesses (Scotland) Act 2014 now defines those under the age of 18 as "children" for the purposes of judicial proceedings.

The 1995 Act provides that "no newspaper report of any proceedings in court shall reveal the name, address or school," or any "particulars calculated to lead to the identification of any person" under the age of 18 , whether they appear as a witness, or as the accused in criminal proceedings. ${ }^{25}$ These publishing restrictions also apply to "sound and television programmes." 26 The publication of photographs is also prohibited. Media organisations which breach this restriction commit a criminal offence, prosecutable summarily, which can give rise to a fine not exceeding level 4 on the standard

\footnotetext{
${ }^{22}$ Id para 6.

${ }^{23}$ Id para 11.

${ }^{24}$ Hereafter, "the 1995 Act."

${ }^{25} 1995$ Act s 47(1).

${ }^{26} 1995$ Act s 47(4).
} 
scale, ${ }^{27}$ but this prohibition can be waived by the court "at any stage of the proceedings," if the judge "is satisfied that this is in the public interest so to do." ${ }^{28}$

In February 2019, Aaron Campbell was convicted of the rape and murder of Alesha MacPhail on the island of Bute. She was six. The accused was 16 years of age. As a result of the 1995 Act's restrictions, newspapers and TV and radio broadcasts did not include Campbell's name or photograph in their coverage of most of his trial. By the time of his conviction, however, Campbell had been identified as the MacPhail's killer by a number of social media users. Significantly, those who did so almost certainly committed no criminal offence. Section 47's restrictions are, after all, limited to traditional media forms and do not extend to Tweeters, YouTubers or Bloggers. When the jury convicted Campbell in March 2019, most of Scotland's media organisations applied to the court to waive section 47's reporting restrictions on publishing his name and photographs. Appearing for Campbell, Brian McConnachie QC argued that "the fact that things may be on social media is not a reason that the court should overrule the prohibition on identifying accused persons who are classified as "children" by law. ${ }^{29}$ Lord Matthews disagreed, authorising the press to name and publish photographs of the convict, as a number of social media users had already done, days before.

\section{G. Conclusion}

Public, press, and political understandings of the legal rules regulating the anonymity of sexual offence complainers in Scottish courts are in a bad shape. The Crown Office's media management strategy, in terms of complainer anonymity, seems orientated principally towards traditional outlets and publications. ${ }^{30}$ This emphasis and the absence of clear legal rules applying to all sexual offence cases exposes complainers to the real risk of public exposure on social media, with no meaningful legal remedies or consequences for those who choose to do so. We need to be sensitive to questions of degree, but in the modern publishing environment, it is not obvious that mainstream media outlets should be treated as uniquely capable of subverting criminal cases when compared to their unregulated and freewheeling counterparts online.

\footnotetext{
${ }^{27} 1995$ Act s 47(5).

281995 Act s 47(3)(b).

${ }^{29}$ BBC Scotland (2019) "Alesha MacPhail murder: Judge lifts ban on naming killer Aaron Campbell” https://www.bbc.co.uk/news/uk-scotland-glasgow-west-47330774.

${ }^{30}$ Though since the conclusion of the case of HM Advocate v Alexander Salmond in March 2020, the Crown have begun proceedings against former ambassador Craig Murray, alleging that blogs posted by him before and during the trial constituted contempt of court. Those proceedings are unresolved at time of writing. $K$ Andrews (2020) "Ex-diplomat Craig Murray charged over Alex Salmond trial" The Times April $24^{\text {th }} 2020$.
} 
Important differences of reach distinguish a report on a flagship national news programme, and the identity of a child witness or a complainer being reported on the Twitter feed of an account with thirteen followers, or on a blog with six hundred readers. But given the circulation figures of many mainstream Scottish newspapers, it is less clear that drawing strong distinctions between the potential impact of traditional publications and broadcasts and interventions by social media accounts with hundreds of thousands of followers - and infinite scope for their tweets and posts to be shared - can be justified. According to the Audit Bureau of Circulations, in January 2020, the Daily Record sold a daily average of 104,339 copies, ${ }^{31}$ while the Scotsman managed $14,417 .{ }^{32}$ Public figures often have social media followings matching or substantially outstripping this potential exposure. On this basis, why should the criminal law draw such stark distinctions between the newspapers' capacity to prejudice the course of justice or undermine complainer anonymity, and high profile social media "influencers"?

In view of the broad social consensus in support of complainer anonymity, and the widespread assumption that provisions like the 1992 Act must apply in Scotland, the gaps in our law seem glaring. Given the critical importance of anonymity to many complainers, given the significant changes feminist law reform efforts have made to Scots law in recent years, given the reassurances the Scottish police give to complainers about their identities being published, it seems remarkable that for more than forty years, complainer anonymity in Scotland has relied on what amounts to little more than a gentleman's agreement by the mainstream media not to identify complainers, special orders under the Contempt of Court Act which are rarely made, and on social media users' decency - or plain misunderstanding of the applicable law.

In the wake of the Salmond trial, this position is not sustainable. Fixing this lacuna in Scots law need not be complex, involved or time-consuming. To extend anonymity rights to Scottish complainers, all Holyrood needs to do is amend the 1992 Act to include historic common law crimes of sexual violence, the new statutory offences created by the Sexual Offences (Scotland) Act 2009, and any other miscellaneous offence politicians judge should be included to the list of those offences attracting complainer anonymity. A standalone Holyrood Bill could have the same effect. Whatever route MSPs pursue, the Scottish Parliament must take the opportunity to reform this aspect of our criminal procedure as a matter of urgency, better to reflect what English law, most journalists, most politicians, and most people in this country already believe law and justice demands.

\footnotetext{
${ }^{31}$ Audit Bureau of Circulations (2020) Daily Record Circulation, January 2020 accessible here: https://www.abc.org.uk/Certificates/49806988.pdf.

${ }^{32}$ Audit Bureau of Circulations (2020) Scotsman Circulation, January 2020 accessible here: https://www.abc.org.uk/Certificates/49625923.pdf.
} 